\title{
MECHANISM OF MULTI-LAYER COMPOSITE COATINGS IN THE ZINC PROCESS OF RECYCLING COATED WC-Co CEMENTED-CARBIDE SCRAP
}

\author{
MEHANIZEM VEČPLASTNIH KOMPOZITNIH PREMAZOV V \\ PROCESU CINKANJA ZA RECIKLIRANJE ODPADKOV \\ OPLAŠČENIH WC-Co KARBIDNIH TRDIN
}

\author{
Hai Kuang ${ }^{1,2}$, Dunqiang Tan ${ }^{1}$, Wen $\mathrm{He}^{1}$, Xiaoru Wang ${ }^{1}$, Jun Zhong1, \\ Huajian Wang', Chenghui Yang ${ }^{1}$ \\ 1Nanchang University, School of Materials Science and Engineering, Nanchang 330031, China \\ 2Jiangxi Science and Technology Normal University, School of Materials and Electromechanics, Nanchang 330038, China \\ tdunqiang@ncu.edu.cn \\ Prejem rokopisa - received: 2017-04-30; sprejem za objavo - accepted for publication: 2017-06-16
}

doi:10.17222/mit.2017.049

\begin{abstract}
The mechanism of a coating is crucial for the zinc-process parameters and zinc-recycled WC powders as well as the subsequent production. The mechanism of a multi-layer composite coating in a zinc process was discussed and the coating with recycled WC powders was studied. The results demonstrated that the coating created a barrier in the zinc process, resulting in a longer recycling time for the coated hard-metal scrap. Furthermore, cracks that appeared due to different thermal-expansion coefficients of the materials were the main reason for the breakdown of the coating, rather than the reaction or the dissolution; and the molten zinc mainly went through cracks. Additionally, the coating elements and fragments were found in the recycled WC powders.

Keywords: zinc process, coated cemented-carbide scrap, recycle, cracks
\end{abstract}

Način in vrsta oplaščenja WC-Co karbidne trdine je ključnega pomena za procesne parametre cinkanja za s cinkom reciklirane WC-prahove, kot tudi za njihovo nadaljnjo obdelavo. V pričujoči raziskavi so avtorji raziskovali vpliv oplaščenja karbidne trdine na proces cinkanja za reciklažo WC-prahov. Rezultati so pokazali, da večslojna prevleka ustvari oviro v procesu cinkanja, kar posledično podaljša čas recikliranja oplaščenih karbidnih trdin. Poleg tega so glavni razlog za pokanje prevlek različni koeficienti toplotnega raztezanja materialov in namesto njihovega raztapljanja poteka infiltracija raztaljenega cinka skozi razpoke do karbidne trdine. Tako so v recikliranem WC prahu našli tudi elemente in delce trdih prevlek.

Ključne besede: cinkanje, odpadki oplaščenih karbidnih trdin, recikliranje, razpoke

\section{INTRODUCTION}

The coated WC-Co cemented-carbide is winning an increasing market share for its good performance. ${ }^{1-4}$ Accordingly, the quantity of coated WC-Co hard-metal scrap is also increasing. However, Tungsten, its main component, has very limited resources worldwide and encounters a supply risk. ${ }^{5,6}$ Therefore, the recycling of WC from coated cemented-carbide scrap is imperative for stringent environmental controls and resource-conservation policies.

In recent years, the recycling of the coated $\mathrm{WC}-\mathrm{Co}$ cemented-carbide scrap has attracted more and more attention. To our knowledge, only a few articles reported it and they mainly focused on the process of recycling. WC-Co hard-metal scrap was reported to be treated directly in sulphuric acid or after removing the coatings by oxidation. ${ }^{7,8}$ However, both of the above would cause serious health and environmental problems. In research, recycled WC powders were obtained with a treatment at a high temperature and a crushing procedure, but the performance was not as good as for virgin powders and needed to be improved..$^{9,10}$ In our previous studies, removing the coating with a chemical method was researched, ${ }^{11}$ but it was difficult to remove the coating completely. Therefore, it is essential to promote a high-efficiency procedure for recycling the WC powders from the coated WC-Co cemented-carbide scrap.

The zinc process, which is one of the most extensively used methods for recovering WC powders, was proved to be efficient and economical. ${ }^{12-14}$ In the zinc process, the molten zinc reacts with $\mathrm{Co}$, and subsequently the bond between the binder and the tungsten carbide grains is broken. As a result, the produced porous tungsten carbide product can be easily mechanically broken. K. Stjernberg ${ }^{15}$ thought that the coating was a hazard for recycling the coated WC-Co cementedcarbide scrap in the zinc process, as it created a barrier to the reaction. Moreover, the mechanism of coating in the zinc process was not clarified. To our knowledge, no scientific literature reported on the mechanism of coatings, the reason for the breakdown of the coated hard metal in the zinc process, and the place where the coating element leaves at the end. All of the three areas 


\section{H. KUANG et al.: MECHANISM OF MULTI-LAYER COMPOSITE COATINGS IN THE ZINC PROCESS ...}

mentioned are crucial to the quality of the recycled WC powders and the process parameters include the recycling time, zinc content and temperature, even in the industrial production of subsequently recycled powders. Therefore, an investigation of the mechanism of the coating in a zinc process becomes significant for tungsten recycling and environmental protection.

In this research, the zinc process was adopted to recycle multi-layer, composite, coated WC-Co hardmetal tool-tip scraps, aiming to provide an understanding of the mechanism of the coatings. The microstructure and mechanism of the coatings were studied; the material interactions among the coatings, zinc and Co were analyzed, and the failure mechanism was also discussed. This work intended to provide valuable information about an efficient zinc process for recycling coated WC-Co cemented-carbide scrap.

\section{EXPERIMENTAL PART}

\subsection{Materials}

The multi-layer composite coated WC-Co cemented-carbide scrap employed for this study was a turning insert after sufficient usage, purchased from a scrap merchant. The dimensions of the sample were $12 \mathrm{~mm} \times$ $12 \mathrm{~mm} \times 5 \mathrm{~mm}$ and its weigh was about $9 \mathrm{~g}$. The chemical composition of the sample mainly included WC
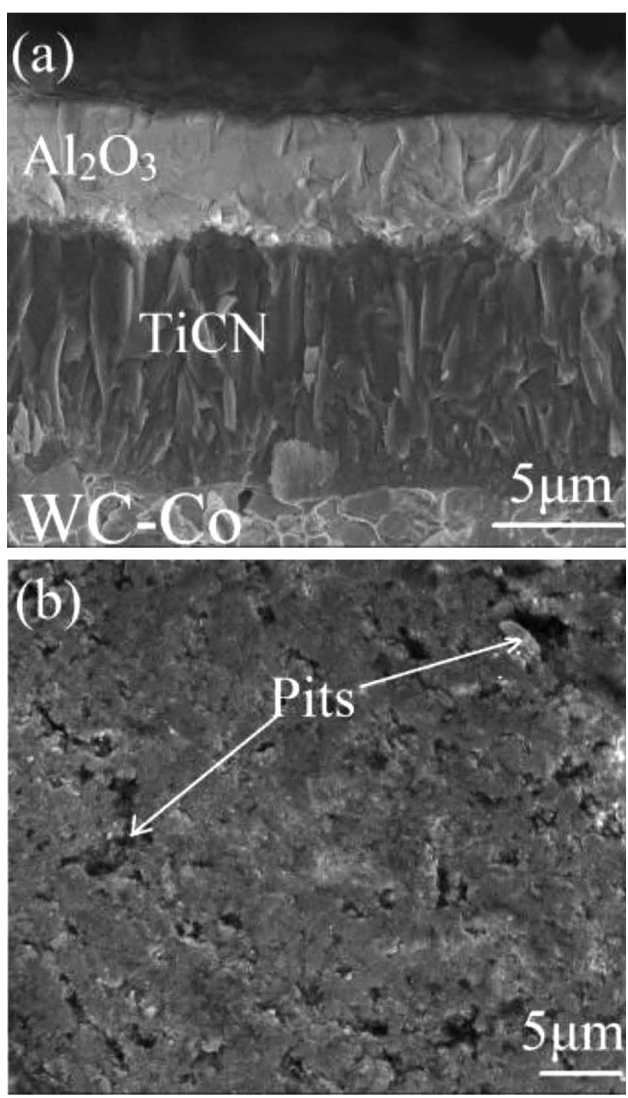

Figure 1: SEM images of multi-layer composite coated WC-Co cemented-carbide scrap: a) cross-section, b) surface and the Co binder (7.41\% mass fraction) and also some other rare elements such as $\mathrm{Ta}, \mathrm{Nb}$ and $\mathrm{Ti}$. Four flanks of the sample were coated with titanium carbonitride $(\mathrm{TiCN})$ /aluminum oxide $\left(\mathrm{Al}_{2} \mathrm{O}_{3}\right) /$ titanium nitride $(\mathrm{TiN})$ through the chemical-vapor-deposition (CVD) method, while the other two faces were covered with TiCN (dark grey) $/ \mathrm{Al}_{2} \mathrm{O}_{3}$ (light grey), as shown in Figure 1a. The top coating, TiN, was removed to reduce the stress. Zinc blocks were cut from zinc ingots with a purity of $99.95 \%$ in order to be conveniently placed in graphite crucibles.

\subsection{Experiment procedure}

The multi-layer, composite, coated WC-Co cemented-carbide scrap was first treated with an ultrasonic cleaner using acetone and ethanol, and the sample was then packed into high-purity graphite crucibles along with pure zinc blocks. The crucible was a hollow cylinder with a 5 -mm inner diameter and 40-mm height. The weight of zinc blocks depends on the Co content in the industry and the preferred weight ratio of zinc to cobalt is usually within a range of about 20:1 to $15: 1 .{ }^{16}$ In our study, the weight ratio of zinc to cobalt was about 50:1. The excessive weight of zinc aimed to research the corrosion behavior in detail. Lids were put on crucibles, and these were then placed in an electric furnace (Yifeng, SX2-4-10). A standard thermocouple was used to check the temperature of the furnace, which was heated from room temperature to $880{ }^{\circ} \mathrm{C}$. A sample and zinc ingots were isothermally maintained at $880{ }^{\circ} \mathrm{C}$. The tips were immersed into molten zinc since the zinc blocks melted at $419.5^{\circ} \mathrm{C}$. The coated hard-metals were treated for $(2,6,9$ and 15) h, while the uncoated samples were treated for (2, 6 and 9$) \mathrm{h}$ during the zinc process. Subsequently, the sample was naturally cooled down to room temperature and then cut using wire-electrode cutting to conveniently examine the interface. In addition, the samples treated with the zinc process for $15 \mathrm{~h}$ were placed in a baker containing a $2 \mathrm{~mol} / \mathrm{L}$ hydrochloric acid aqueous solution. $\mathrm{Zn}$ and $\mathrm{Co}$ were dissolved in the solution, while WC was deposited on the bottom as a solid. After being washed with water, the solution was filtrated and dried to obtain the WC powder.

The WC-Co cemented-carbide scrap in the zinc process from the photographs was examined using an optical microscope. The micromorphologies were investigated with a field-emission scanning electron microscope (FESEM), whilst the element compositions of the samples were characterized using energy-dispersive $\mathrm{X}$-ray spectroscopy (EDS). The inductively-coupledplasma method (ICP, optima 5300DV) was employed to test the element content of the recycled powder. Recycled products of the WC-Co scrap samples were identified using an X-ray diffractometer (XRD; PANalytical, EMPYREAN). 


\section{RESULTS AND DISCUSSION}

\subsection{Multi-layer composite coated WC-Co cemented- carbide scrap in the zinc process}

The macrostructures of the multi-layer, composite, coated WC-Co cemented-carbide scrap treated with the zinc process were characterized. Figure 2 includes cross-section images of the WC-Co cemented carbides in the zinc process after cooling down and solidification. Obvious changes can be observed. As shown in Figure 2a, a few cracks could be clearly observed in the sample having been treated at $880{ }^{\circ} \mathrm{C}$ for $2 \mathrm{~h}$. Zinc got into the samples mainly through the cracks. The volume of scrap expanded and more cracks were found after having been treated for $9 \mathrm{~h}$ (as shown in Figure 2b). As shown in Figure 2c, the substrate was dispersed in zinc after a treatment for $15 \mathrm{~h}$. Figures $\mathbf{2 d}$ and $\mathbf{2 e}$ show the uncoated WC-Co cemented-carbides scrap. It can be found that the samples could not even maintain the square shape after the $2-\mathrm{h}$ treatment and the $\mathrm{WC}$ particles were distributed in zinc only after the 9-h treatment. The results demonstrated that the coating was a barrier in the zinc process. More time was required to recover the WC powders from the coated WC-Co cemented-carbide scrap.
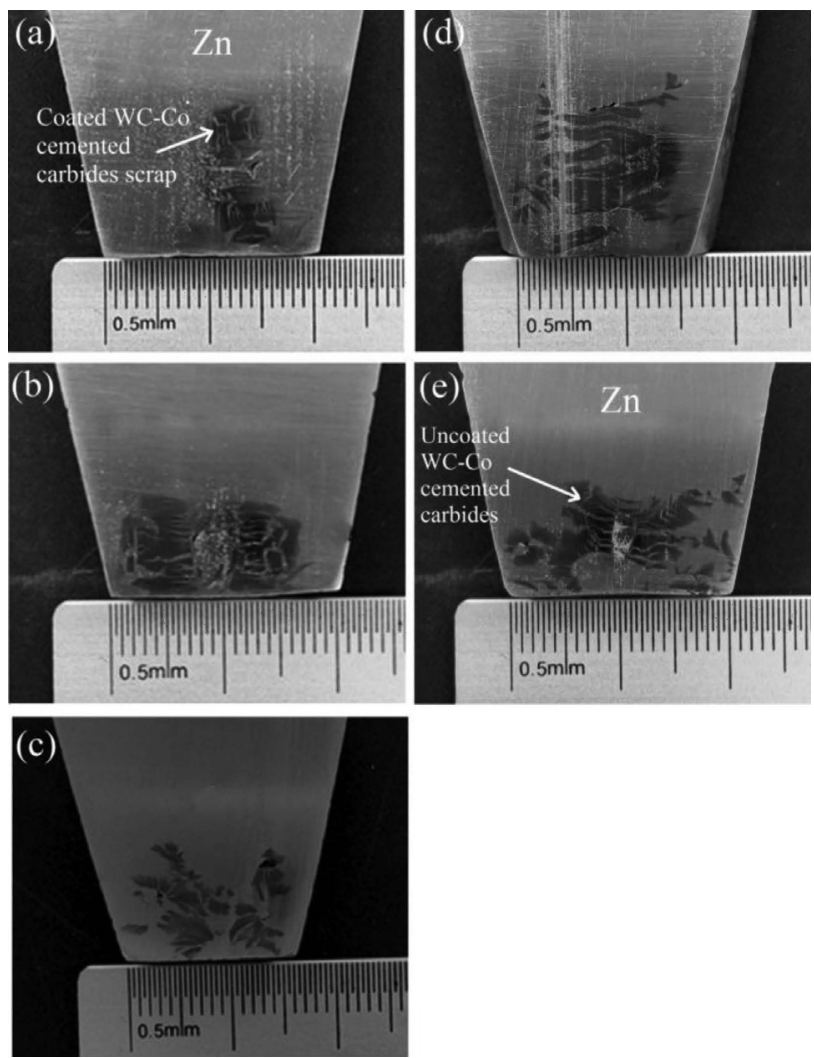

Figure 2: Photographs of coated and uncoated WC-Co cementedcarbide scraps in the zinc process: a) coated sample treated for $2 \mathrm{~h}$, b) coated sample treated for $9 \mathrm{~h}, \mathrm{c}$ ) coated sample treated for $15 \mathrm{~h}, \mathrm{~d}$ ) uncoated sample treated for $2 \mathrm{~h}$, e) uncoated sample treated for $9 \mathrm{~h}$

\subsection{Characterization of the recycled powders}

Figure 3 shows the results for the recycled WC particles. The substrate of the coated sample treated with the zinc process for $15 \mathrm{~h}$ was characterized for comparison. As seen in Figure 3b, the substrate (WC) was dispersed in zinc, revealing that the coating was broken and $\mathrm{Zn}$ completely reacted with Co. It can be observed that the substrate was porous and loose, and can be easily broken down mechanically. ${ }^{17}$ So, recycling the coated WC-Co cemented-carbide scrap during the zinc process was feasible, though the coating created a barrier to the reaction. The recycled WC powders obtained in the present study can be seen in Figure 3. It can be seen that the coating was found among the WC particles. EDS results show the $\mathrm{Al}$ element is in the powders recycled from the coated scrap; but this element could not be found in the powders obtained from the uncoated samples, as shown in Figure 3d. However, only WC was found with the XRD (Figure 3f). The amount of $\mathrm{Al}$ in the recycled powders was only $78 \mathrm{mg} / \mathrm{kg}$, which was difficult to detect with the XRD analysis.
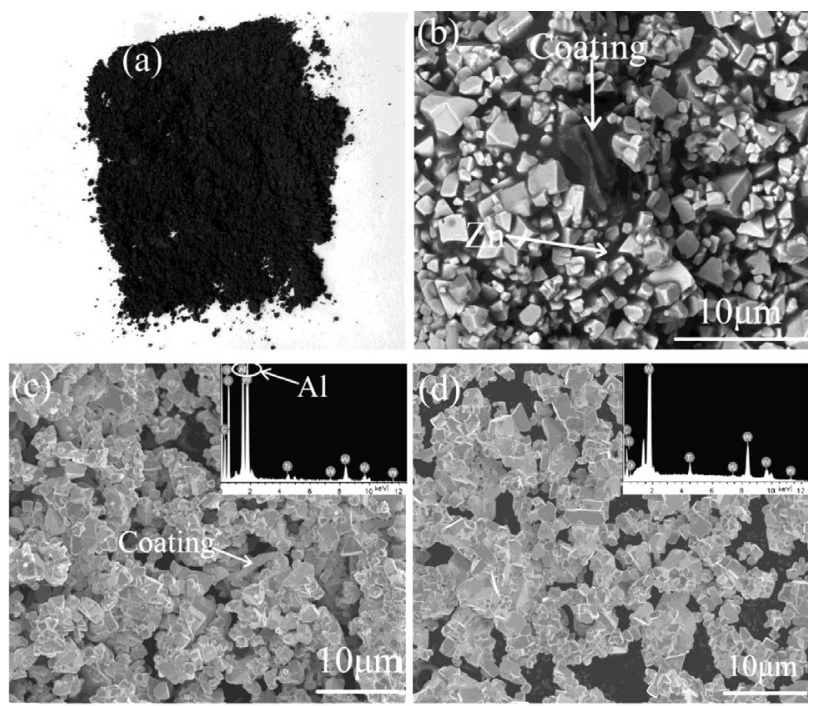

(e)

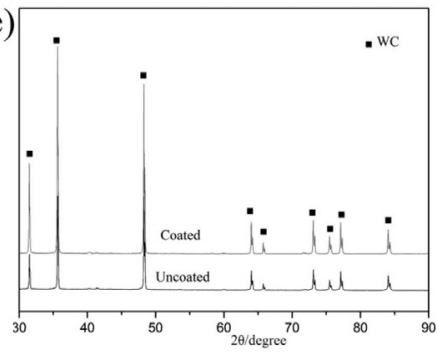

Figure 3: Results for recycled WC powders: a) photograph of recycled WC powders from coated samples, b) cross-section of WC particles in the substrate of the coated sample in the zinc process for $15 \mathrm{~h}, \mathrm{c})$ SEM image and EDS result for the recycled WC powders of coated samples, d) SEM image and EDS result for the recycled WC powders of uncoated samples, e) XRD result 


\subsection{Material interactions}

\subsubsection{Chemical reactions among the coatings, $\mathrm{Zn}$ and Co}

When the molten zinc is in contact with $\mathrm{TiCN} / \mathrm{Al}_{2} \mathrm{O}_{3}$, these are possible reactions:

$$
\begin{aligned}
3 \mathrm{Zn}+\mathrm{Al}_{2} \mathrm{O}_{3} & \rightarrow 2 \mathrm{Al}+3 \mathrm{ZnO} \\
\mathrm{Zn}+\mathrm{TiCN} & \rightarrow \mathrm{TiC}+\mathrm{ZnN} \\
9 \mathrm{Co}+4 \mathrm{Al}_{2} \mathrm{O}_{3} & \rightarrow 3 \mathrm{Co}_{3} \mathrm{O}_{4}+8 \mathrm{Al} \\
\mathrm{TiCN}+\mathrm{Co} & \rightarrow \mathrm{Co}_{3} \mathrm{~N}+\mathrm{TiC}
\end{aligned}
$$

The thermodynamic parameters are calculated and the standard free-energy change of the equations above are all over zero $(\Delta G>0)$. According to the analysis of the thermodynamics, $\mathrm{Al}_{2} \mathrm{O}_{3}$ and $\mathrm{TiCN}$ could not react with $\mathrm{Zn}$ or $\mathrm{Co}$ on this condition. This is consistent with the fact that $\mathrm{Al}_{2} \mathrm{O}_{3}$ is usually used to be the anti-corrosion material for the zinc corrosion. ${ }^{18}$ The chemical reaction is not the main factor for the failure of the coated WC-Co cemented-carbide scrap in the zinc process.

\subsubsection{Dissolution and diffusion}

The molten-zinc corrosion occurs together with the physical effect, not a general chemical reaction, and the physical effect leads to the failure of the material. The most important ways are dissolution and diffusion. ${ }^{19-21}$ For a better understanding of the mechanism, the element mapping of the sample in the zinc process was further studied, as shown in Figure 4. It can be seen that Co was distributed in the zinc-enrichment area due to the fact that $\mathrm{Zn}$ reacts with Co. But only some Co could be found at the position of the coatings. Moreover, most coating elements, like $\mathrm{Al}$ and $\mathrm{Ti}$, were distributed along the coating location, revealing that coatings $\mathrm{Al}_{2} \mathrm{O}_{3}$ and TiCN could not dissolve or diffuse much in the molten zinc and Co. Therefore, the physical effect of dissolution
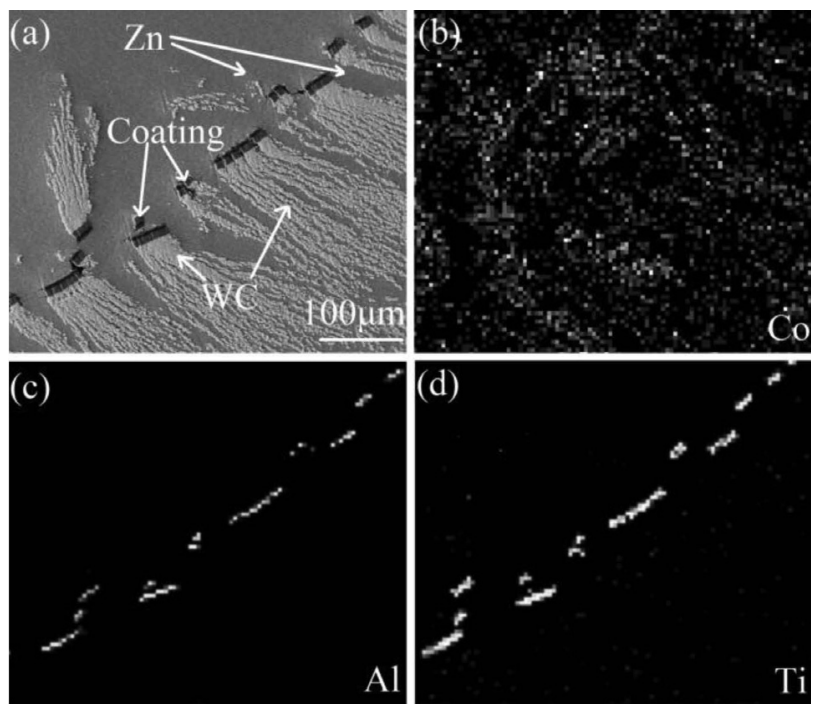

Figure 4: Element mapping for multilayer, composite, coated, WC-Co cemented-carbide scrap in zinc process and diffusion was not the main reason for the breaking down of the multilayer, composite, coated WC-Co cemented-carbide scrap in the zinc process. Near the WC particles, it can be seen that there are a few Ti particles, which were contained in the substrate of the tip.

\subsubsection{Pits and cracks}

Figures 5 and $\mathbf{6}$ show the surface and cross-section images of the multilayer, composite, coated WC-Co cemented-carbide scrap in the zinc process for different times. As seen in Figure 5a, the zinc residue on the surface of the coating was in the shape of a sphere, demonstrating that $\mathrm{Al}_{2} \mathrm{O}_{3}$ is not well wetted by zinc, which can delay the penetration of molten zinc into the substrate. $^{22}$ Previous researches ${ }^{19,23}$ revealed that the corrosion of the materials poorly wetted by zinc was caused by surface defects, usually pits and cracks. They could provide preferential paths for transporting the molten zinc to the coatings and the substrate. Therefore, defects are vulnerable to molten zinc.

In the present study, the multi-layer, composite, coated WC-Co cemented-carbide scrap was worn out. As seen in Figure 1, the localized areas of the coating began to disintegrate, especially at the corners and flanks. ${ }^{24,25} \mathrm{~A}$ number of defects were observed on the surfaces of the samples. Pits could be generated during the deposition of coatings or appear during the cutting of alloys. ${ }^{23}$ Most pits were concentrated on damaged local edges and corners. In this study, the pits provided the paths for transporting the molten zinc. The molten zinc could penetrate inwards via intergranular boundaries of the coatings (Figure 5a). Therefore, the pits were the reason for the failure of the coatings. Pits in coatings are inversely proportional to the coating resistance, i.e., a lot of pits with a larger size lead to an easier coating breakdown. ${ }^{26}$ It can be seen from Figures $\mathbf{5}$ and $\mathbf{6}$ that not much zinc
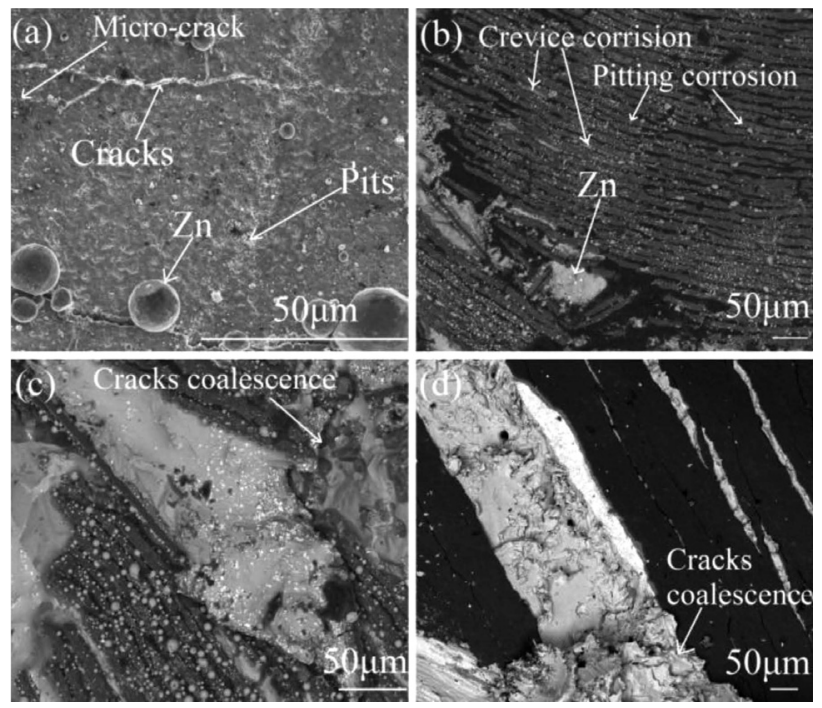

Figure 5: Surface SEM images of multi-layer, composite, coated WC-Co cemented-carbide scrap in zinc process for different times: a) $2 \mathrm{~h}, \mathrm{~b}) 6 \mathrm{~h}$, c) $9 \mathrm{~h}$, d) $15 \mathrm{~h}$ 


\section{H. KUANG et al.: MECHANISM OF MULTI-LAYER COMPOSITE COATINGS IN THE ZINC PROCESS ..}

got into the samples through the pits as the coating created a barrier.

Most of zinc got into the samples through cracks, as shown in Figures 5 and 6. When coatings are deposited, cracks are created due to the lattice mismatch. As shown in Figures $\mathbf{6 a}$ to $\mathbf{6 d}$, the molten zinc reached the substrate mainly by penetrating the cracks. At the early stage, pits also lead to the formation of microcracks with the increasing treating time. Most of these cracks were generated during the cutting or heating of the metals due to a difference between the thermal-expansion coefficients of the substrate and coating materials (Table 1). ${ }^{27}$ Stress was the main reason for an increased number of larger cracks. ${ }^{28}$ Furthermore, the exfoliation of the coatings contributed to an increased crack coalescence. ${ }^{29}$

Table 1: Thermal-expansion coefficients of materials

\begin{tabular}{|c|c|c|c|c|c|}
\hline Material & $\mathrm{TiN}$ & $\mathrm{Al}_{2} \mathrm{O}_{3}$ & $\mathrm{TiCN}$ & $\mathrm{WC}$ & $\mathrm{Zn}$ \\
\hline $\begin{array}{l}\text { Thermal-expansion } \\
\text { coefficient }\left(10^{-6} \mathrm{~K}\right)\end{array}$ & 9.35 & 9.0 & 7.8 & 4.3 & 30.2 \\
\hline
\end{tabular}

Zinc went through pits and microcracks at the early stage (Figures 5a and 6a). Then the number of pits increased and they became deeper and larger with the increasing treatment time; the cracks also increased due to the expansion. The converging of microcracks also led
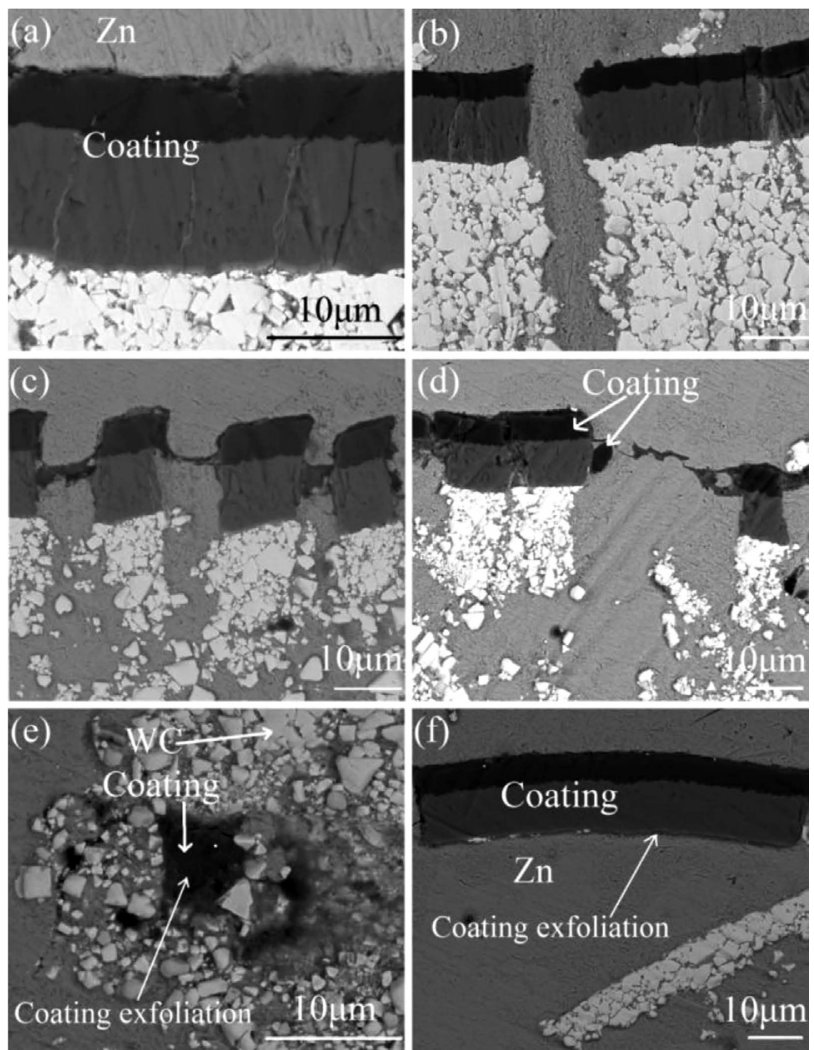

Figure 6: Cross-section SEM images of multi-layer, composite, coated WC-Co cemented-carbide scrap in zinc process for different times: a) $2 \mathrm{~h}$, b) $6 \mathrm{~h}, \mathrm{c}) 9 \mathrm{~h}$, d) $15 \mathrm{~h}$, e) coatings distributed among WC particles in the zinc process of $15 \mathrm{~h}, \mathrm{f}$ ) coatings distributed in the zinc-enriched area in the zinc process of $15 \mathrm{~h}$
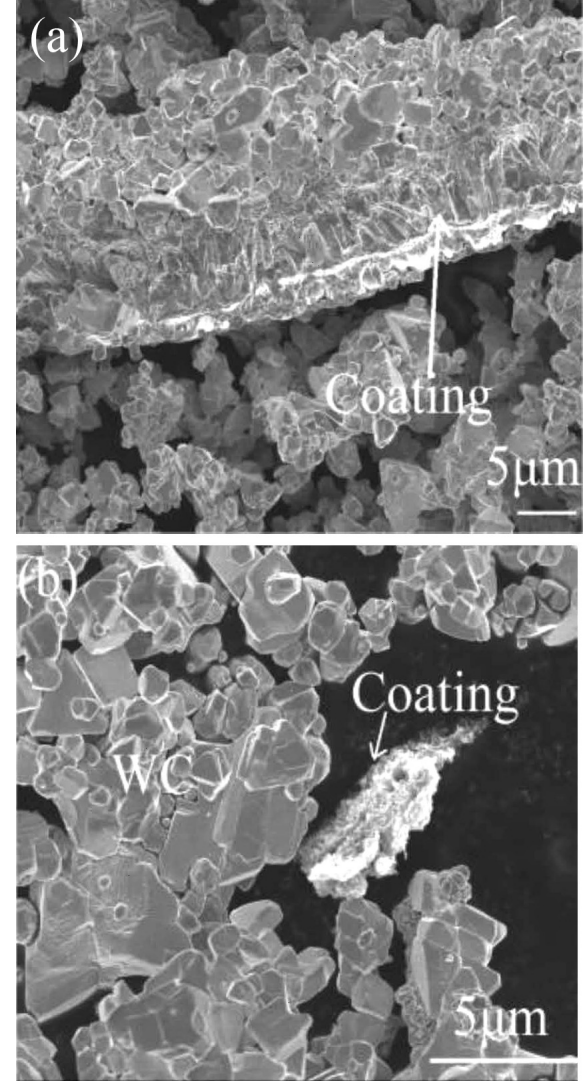

Figure 7: SEM images of the coatings in recycled WC powders

to wide cracks. It can be seen that at the early stage, a crack (Figure 5a) has a width of less than $5 \mu \mathrm{m}$, and at the last stage, a wide crack (Figure 5d) has a width of more than $230 \mu \mathrm{m}$. This led to a localized breakdown of a coating. Several coatings even became detached from the substrate with the increasing treating time, as shown in Figures 6e and 6f. During the last stage, the samples were dispersed. Most WC particles were separated in zinc due to the dissolution of the Co binder. Localized breakdowns of the coatings and substrates can be observed. Some coatings were torn into pieces and deviated from the original position. Several coating elements can be found among the WC particles (Figure 6e) or in the zinc-enriched region (Figure 6f). This indicates that the molten zinc mainly got in through the cracks, and it was the main mechanism of the failure coatings, which is also demonstrated with the element mapping in Figure 4. The result is consistent with the conclusion that the formation and extension of cracks is the main reason for the breakdown of coated carbide tools in the zinc process. ${ }^{30}$

In order to further study the corrosion behavior of the multi-layer, composite coating, recycled WC powders were characterized with SEM as shown in Figure 7. Coating fragments flaking off were found. Some were tightly bound with the WC particles (Figure 7a) and others were on their own among the WC particles. That is in good agreement with the result from Figure 6. 


\section{CONCLUSIONS}

The mechanism of a coating in a zinc process influences the properties of the recycled powders, the recycling process and thus the subsequent industrial production. In this study, the breakdown of a multi-layer composite coating was investigated. The results show that the coating delayed the reaction of $\mathrm{Zn}$ and $\mathrm{Co}$ in the zinc process; therefore, a longer time was needed for recycling coated hard-metal scraps. Both the pits and cracks were the reason for the failure of the coatings in the zinc process and zinc got into the samples mainly through the cracks, most of which appeared due to different thermal-expansion coefficients of the materials. After the treatment in the zinc process for $15 \mathrm{~h}$, the substrate became porous and loose. WC powders were successfully obtained from the multi-layer, composite, coated WC-Co cemented-carbide scrap with the zinc process, and stripped coatings were found in the recycled WC powders. This investigation can provide some fundamental information needed to develop an efficient recycling method for multi-layer, composite, coated WC-Co cemented-carbide scrap.

\section{Acknowledgement}

This work was supported by the National Natural Science Foundation of China (51564036 and 50904035), the National High-Tech R\&D Program of China (2012AA061902) and the National Key Technology R\&D Program of China (2011BAC10B04).

\section{REFERENCES}

${ }^{1}$ L. Y. Zhou, J. T. Ni, Q. H, Study on failure mechanism of the coated carbide tool, International Journal of Refractory Metals and Hard Materials, 25 (2007) 1, 1-5, doi:10.1016/j.ijrmhm.2005.10.002

${ }^{2}$ G. J. Ma, L. L. Wang, H. X. Gao, J. Zhang, T. Reddyhoff, The friction coefficient evolution of a TiN coated contact during sliding wear, Applied Surface Science, 345 (2015), 109-115, doi:10.1016/ j.apsusc. 2015.03 .156

${ }^{3}$ Q. Z. Wang, F. Zhou, X. N. Wang, K. M. Chen, M. L. Wang, T. Qian, Y. X. Li, Comparison of tribological properties of $\mathrm{CrN}$, TiCN and TiAlN coatings sliding against $\mathrm{SiC}$ balls in water, Applied Surface Science, 25 (2011), 7813-7820, doi:10.1016/j.apsusc.2011.04.035

${ }^{4}$ K. J. Brookes, Hardmetals group studies coatings, Metal Powder Report, 69 (2014) 2, 22-27, doi:10.1016/S0026-0657(14)70080-3

${ }^{5}$ T. Yamaguchi, H. Hagino, Y. Michiyama, Sliding Wear Properties of Ti/TiC Surface Composite Layer Formed by Laser Alloying, Materials Transactions, 56 (2015) 3, 361-366, doi:10.2320/matertrans. m2014330

${ }^{6}$ T. Ishlda, T. Itakura, H. Morlguchl, A. Ikegaya, Development of technologies for recycling cemented carbide scrap and reducing tungsten use in cemented carbide tools, Sei Technical Review, 75 (2012) 75, 38-46

${ }^{7}$ W. H. Gu, Y. S. Jeong, K. Kim, J. C. Kim, S. H. Son, S. Kim, Thermal oxidation behavior of WC-Co hard metal machining tool tip scraps, Journal of Materials Processing Technology, 212 (2012) 6, 1250-1256, doi:10.1016/j.jmatprotec.2012.01.009

${ }^{8}$ C. D. Vanderpeel, R. A. Seheithauer, R. G. Warmington, Recovery of refractory metal values from scrap cemented carbide, US Patent, 4432950 (1984)
${ }^{9}$ Z. J. Wu, P. Zhang, J. S. Zeng, Z. Y. Deng, The process of producing cemented carbide by recycled WC powders, Cemented Carbide, 22 (2005) 3, 170-172, doi:10.3969/j.issn.1003-7292.2005.03.010

${ }^{10}$ Z. J. Wu, J. Liu, Research on removing of the coating from the coated cemented carbide, Non-ferrous metals recycling and utilization, 7 (2005) 2, 19-20

${ }^{11}$ Y. Liu, D. Q. Tan, D. P. Lu, L. Lei, J. Long, Corrosion behavior in process of removing TiN coating of waste cemented carbide by chemical method, Materials Science and Engineering of Powder Metallurgy, 18 (2013) 1, 20-25, doi:10.3969/j.issn.1673-0224.2013. 01.006

${ }^{12}$ K. J. Brookes, Hardmetals recycling and the environment, Metal Powder Report, 69 (2014) 5, 24-30, doi:10.1016/S0026-0657(14) 70225-5

${ }^{13}$ C. S. Freemantle, N. Sacks, M. Topic, C. A. Pineda-Vargas, PIXE as a characterization technique in the cutting tool industry, Nuclear Instruments and Methods in Physics Research Section B: Beam Interactions with Materials and Atoms, 318 (2014) 1, 168-172, doi:10.1016/j.nimb.2013.06.044

${ }^{14}$ E. Altuncu, F. Ustel, A. Turk, S. Ozturk, G. Erdogan, Cutting-tool recycling process with the zinc-melt method for obtaining thermal-spray feedstock powder (WC-Co), Materiali in Tehnologije, 47 (2013) 1, 115-118

${ }^{15}$ K. Stjernberg, J. Johnson, Recycling of cemented carbides, Metal Powder Report, 53 (1998) 12, 40, doi:10.1016/s0026-0657(99) 80135-0

${ }^{16}$ P. G. Barnard, A. G. Starliper, H. Kenworthy, Reclamation of refractory carbides from carbide materials, US Patent 3595484 (1971)

${ }^{17}$ J. C. Liu, S. W. Park, S. Nagao, M. Nogi, H. Koga, J. S. Ma, G. Zhang, K. Suganuma, The role of $\mathrm{Zn}$ precipitates and $\mathrm{Cl}$-anions in pitting corrosion of $\mathrm{Sn}-\mathrm{Zn}$ solder alloys, Corrosion Science, 92 (2015), 263-271, doi:10.1016/j.corsci.2014.12.014

${ }^{18}$ Y. H. Lv, X. S. Wu, Y. F. Liu, Z. J. Wu, Preparation of $\mathrm{Al}_{2} \mathrm{O}_{3}-\mathrm{TiB}_{2}$ composite ceramic coating and corrosion-resistant property to molten zinc, China surface engineering, 24 (2011) 4, 30-33, doi:10.3969/ j.issn.1007-9289.2011.04.006

${ }^{19}$ X. J. Ren, X. Z. Mei, J. She, J. H. Ma, Materials resistance to liquid zinc corrosion on surface of sink roll, Journal of Iron and Steel Research, International, 14 (2007) 5, 130, doi:10.1016/S1006706X(08)60066-7

${ }^{20}$ M. P. Taylor, J. R. P. Smith, H. E. Evans, Modelling of the interdiffusion and oxidation of a multilayered chromia forming thermal barrier coating, Materials and Corrosion, 68 (2016) 2, 215-219, doi:10.1002/maco.201508778

${ }^{21}$ X. D. Tian, X. P. Guo, Z. P. Sun, J. L. Qu , L. J. Wang, Oxidation resistance comparison of $\mathrm{MoSi} 2$ and $\mathrm{B}$-modified $\mathrm{MoSi} 2$ coatings on pure Mo prepared through pack cementation, Materials and Corrosion, 66 (2014) 7, 681-687, doi:10.1002/maco.201407631

${ }^{22}$ J. F. Zhang, C. M. Deng, J. B. Song, C. G. Deng, M. Liu, K. S. Zhou, $\mathrm{MoB}-\mathrm{CoCr}$ as alternatives to $\mathrm{WC}-12 \mathrm{Co}$ for stainless steel protective coating and its corrosion behavior in molten zinc, Surface and Coatings Technology, 235 (2013), 811-818, doi:10.1016/j.surfcoat. 2013.08.052

${ }^{23}$ A. A. Matei, I. Pencea, M. Branzei, D. E. Tranca, G. Tepes, C. E. Sfat, E. Ciovica, A. I. Gherghilescu, G. A. Stanciu, Corrosion resistance appraisal of TiN, TiCN and TiAlN coatings deposited by CAE-PVD method on WC-Co cutting tools exposed to artificial sea water, Applied Surface Science, 358 (2015), 572-578, doi:10.1016/ j.apsusc.2015.08.041

${ }^{24}$ J. D. Brassard, D. K. Sarkar, J. Perron, A. Audibert-Hayet, D. Melot, Nano-micro structured superhydrophobic zinc coating on steel for prevention of corrosion and ice adhesion, Journal of Colloid and Interface Science, 447 (2015), 240-247, doi:10.1016/j.jcis.2014. 11.076

${ }^{25}$ D. Zhang, B. Shen, F. Sun, Study on tribological behavior and cutting performance of CVD diamond and DLC films on Cocemented tungsten carbide substrates, Applied Surface Science, 256 (2010) 8, 2479-2489, doi:10.1016/j.apsusc.2009.10.092 


\section{MATERIALI IN TEHNOLOGIJE/MATERIALS AND TECHNOLOGY (1967-2017) - 50 LET/50 YEARS}

\section{H. KUANG et al.: MECHANISM OF MULTI-LAYER COMPOSITE COATINGS IN THE ZINC PROCESS ...}

${ }^{26}$ M. Karbasi, M. R. Zamanzad Ghavidel, A. Nekahi, Corrosion behavior of HVOF sprayed coatings of $\mathrm{Ni}$ TiC and Ni (Ti,W)C SHS produced composite powders and $\mathrm{Ni}+\mathrm{TiC}$ mixed powder, Materials and Corrosion, 65 (2012) 5, 485-492, doi:10.1002/maco.201206536

${ }^{27}$ A. Matthews, Handbook of hard coatings, Edited by Rointan E. Bunshah, (2001), 203-205

${ }^{28}$ C. Lee, H. Park, J. Yoo, C. Lee, W. C. Woo, S. Park, Residual stress and crack initiation in laser clad composite layer with Co-based alloy and WC+NiCr, Applied Surface Science, 345 (2015), 286-294, doi:10.1016/j.apsusc.2015.03.168
${ }^{29}$ H. B. Wang, X. Z. Wang, X. Y. Song, X. M. Liu, X. W. Liu, Sliding wear behavior of nanostructured WC-Co-Cr coatings, Applied Surface Science, 355 (2015), 453-460, doi:10.1016/j.apsusc.2015. 07.144

${ }^{30}$ Y. J. Zheng, Y. X. Leng, X. Xin, Z. Y. Xu, F. Q. Jiang, R. H. Wei, N. Huang, Evaluation of mechanical properties of $\mathrm{Ti}(\mathrm{Cr}) \mathrm{SiC}(\mathrm{O}) \mathrm{N}$ coated cemented carbide tools, Vacuum, 90 (2013) 2, 50-58, doi:10.1016/j.vacuum.2012.10.002 